\title{
Redox Regulation of Pro-IL-1 $\beta$ Processing May Contribute to the Increased Severity of Serum-Induced Arthritis in NOX2-Deficient Mice
}

\author{
Ya-Fang Huang, Pei-Chi Lo, Chia-Liang Yen, ${ }^{2}$ Peter Andrija Nigrovic, ${ }^{3,4}$ Wen-Chen Chao, ${ }^{1,5}$ \\ Wei-Zhi Wang, George Chengkang Hsu, Yau-Sheng Tsai, and Chi-Chang Shieh ${ }^{1,6}$
}

\begin{abstract}
Aims: To elucidate the role of reactive oxygen species (ROS) in arthritis and to identify targets of arthritis treatment in conditions with different levels of oxidant stress. Results: Through establishing an arthritis model by injecting arthritogenic serum into wild-type and NADPH oxidase 2 (NOX2)-deficient mice, we found that arthritis had a neutrophilic infiltrate and was more severe in $\mathrm{Ncfl}^{-/-}$mice, a mouse strain lacking the expression of the $\mathrm{NCF} 1 / \mathrm{p} 47^{\text {phox }}$ component of NOX2. The levels of interleukin- $1 \beta$ (IL-1 $\beta$ ) and IL-6 in inflamed joints were higher in $N c f 1^{-/-}$than in controls. Antagonists of tumor necrosis factor- $\alpha(\mathrm{TNF} \alpha)$ and IL-1 $\beta$ were equally effective in suppressing arthritis in wild-type mice, while IL-1 $\beta$ blockade was more effective than TNF $\alpha$ blockade in $N c f 1^{-1-}$ mice. A treatment of caspase inhibitor and the combination treatment of a caspase inhibitor and a cathepsin inhibitor, but not a cathepsin inhibitor alone, suppressed arthritic severity in the wild-type mice, while a treatment of cathepsin inhibitor and the combination treatment of a caspase inhibitor and a cathepsin inhibitor, but not a caspase inhibitor alone, were effective in treating $\mathrm{Ncf1}^{-/-}$mice. Consistently, cathepsin B was found to proteolytically process pro-IL- $1 \beta$ to its active form and this activity was suppressed by ROS. Innovation: This novel mechanism of a redox-mediated immune regulation of arthritis through leukocyte-produced ROS is important for devising an optimal treatment for patients with different levels of tissue ROS. Conclusion: Our results suggest that ROS act as a negative feedback to constrain IL- $1 \beta$-mediated inflammation, accounting for the more severe arthritis in the absence of NOX2. Antioxid. Redox Signal. 23, 973-984.
\end{abstract}

\section{Introduction}

I MMUNE-MEDIATED ARTHRITIS, including rheumatoid arthritis (RA) and juvenile idiopathic arthritis (JIA), is a family of chronic inflammatory diseases of the joints, which affects up to $1 \%$ of the human population worldwide. These debilitating diseases not only decrease personal productivity and worsen life quality but also incur enormous medical cost. With the increasing use of biological response modifiers (biologics) in the treatment of immune-mediated arthritis, the financial burden on healthcare systems is likely to continue growing $(15,24,29)$.

The pathogenic mechanisms of immune-mediated arthritis have been intensively investigated, establishing roles for autoreactive $\mathrm{T}$ cells and autoantibodies in local and systemic inflammation $(16,28)$. The importance of innate immune cells, including neutrophils, mast cells, and innate lymphoid cells in the initiation and perpetuation of immune-mediated arthritis, has also been revealed in recent years $(5,11,41)$.

Institutes of ${ }^{1}$ Clinical Medicine and ${ }^{2}$ Basic Medical Science, National Cheng Kung University College of Medicine, Tainan, Taiwan.

${ }^{3}$ Division of Rheumatology, Immunology, and Allergy, Brigham and Women's Hospital, Boston, Massachusetts.

${ }_{5}^{4}$ Division of Immunology, Boston Children's Hospital, Boston, Massachusetts.

${ }^{5}$ Department of Internal Medicine, Taichung Veteran General Hospital, Chiayi Branch, Chiayi, Taiwan.

${ }^{6}$ Department of Pediatrics, National Cheng Kung University Hospital, Tainan, Taiwan.

(C) Ya-Fang Huang et al. 2015; Published by Mary Ann Liebert, Inc. This Open Access article is distributed under the terms of the Creative Commons Attribution Noncommercial License (http://creativecommons.org/licenses/by-nc/4.0/) which permits any noncommercial use, distribution, and reproduction in any medium, provided the original author(s) and the source are credited 


\section{Innovation}

By addressing the role of redox regulation in immunemediated joint inflammation, this current investigation revealed a novel mechanism through which NADPH oxidase 2 (NOX2)-deficient individuals with early arthritis produce higher levels of interleukin-1 $\beta$ (IL-1 $\beta$ ) and hence more severe arthritis. A previously overlooked negative feedback loop through which leukocyte-produced reactive oxygen species help to moderate the severity of tissue inflammation was delineated, which may help to define optimal treatment for patients with immune-mediated arthritis.

Cytokines produced by leukocytes play a critical role in the pathogenesis of immune-mediated arthritis $(4,53)$. Innate immune cells produce inflammatory cytokines and other mediators to initiate tissue inflammation when they encounter activation signals such as pathogen-associated molecule patterns or damage-associate molecular patterns. Tumor necrosis factor- $\alpha(\mathrm{TNF} \alpha)$ and interleukin-1 $\beta$ (IL-1 $\beta)$, produced in abundance by phagocytic leukocytes (e.g., neutrophils and macrophages), are the most studied acute inflammatory cytokines in immune-mediated arthritis and have been used as therapeutic targets in clinical treatment (53). TNF $\alpha$ is synthesized as a peptide with a signal sequence in the endoplasmic reticulum and is released through the classical secretory pathway of Golgi apparatus and secretory vesicles (32). In contrast, IL-1 $\beta$ lacks a secretory signal peptide and is externalized through a still poorly defined pathway. Pro-IL- $1 \beta$ is synthesized in the cytosol as an inactive precursor that is then activated by catalytic proteases before it is secreted as active IL-1 $\beta(2,38)$.

Among the phagocytic leukocytes, neutrophils have been noted to be preferentially recruited into the inflamed joint (27, $30,57)$. These activated neutrophils produce a large amount of reactive oxygen species (ROS) in inflammatory tissues and lead to a state of oxidant stress in the inflammatory arthritis (19). The major source of these oxidants is NADPH oxidase 2 (NOX2), which is highly expressed in leukocytes and comprises a membrane-bound flavocytochrome b558 (assembled from gp91phox and p22phox) and at least four cytosolic components (p67phox, p47phox, p40phox, and Rac GTPases) (3, 46). Although the ROS produced by leukocytes have been reported to be proinflammatory in many immune-mediated diseases (23), the role of leukocyte-produced ROS in the pathogenesis of immune-mediated arthritis has been questioned from the early studies (56). Antioxidants have been shown to reduce cartilage damage in animal models of RA $(1,62)$. However, some recent studies have shown that low oxidant stress in the joint tissue may increase arthritis susceptibility and disease severity $(21,42)$.

How the oxidant stress in joint inflammation affects the pathogenesis of arthritis remains to be unraveled. In this study, we used the $\mathrm{K} / \mathrm{BxN}$ serum-induced arthritis model in wild-type and NOX2-deficient mice to ask whether and how leukocyte-mediated redox regulation plays a role in the pathogenesis of immune-mediated arthritis.

\section{Results}

\section{Serum-induced joint inflammation was more severe in NOX2-deficient mice}

To address the role of leukocyte-induced oxidant stress in joint inflammation, we used the $\mathrm{K} / \mathrm{BxN}$ serum-induced ar- thritis mouse model, which has been shown to be a good model for studying systemic as well as local inflammation in arthritis (39). We induced arthritis in $\mathrm{Ncfl}^{-/-}$and $\mathrm{Cybb}^{-/-}$mice (the strains with defects in genes encoding $\mathrm{p} 47$ phox and gp91phox of NOX2, respectively) and Nos $2^{-/-}$(the strain with the defective gene encoding inducible nitric oxide synthase [iNOS]) along with control wild-type mice. The functional defects of the leukocytes from their respective mouse strains were confirmed with direct measurement of ROS or NO production from the leukocytes (Supplementary Fig. S1; Supplementary Data are available online at www.liebertpub.com/ars). The severity of the serum-induced arthritis was measured with joint swelling (thickening) and clinical scores of each mouse for 7 days. We found that the severity of joint swelling was similar in wild-type and Nos $2^{-/-}$mice. However, the joint swelling in both $\mathrm{Ncfl}^{-/-}$and $C y b b^{-/-}$mice was significantly more severe when compared with wild-type controls (Fig. 1). We also tested the potential interaction between ROS and reactive nitrogen species (RNS) by inducing arthritis in $N c f 1^{-/-} N o s 2^{-/-}$ mice. We found that the arthritic severity in $N c f 1^{-/-} N o s 2^{-/-}$ mice was similar to that in $\mathrm{Ncfl}^{-/-}$or $\mathrm{Cybb^{-/- }}$ mice. These data suggested that NOX2-produced ROS may ameliorate serum-induced arthritis, whereas iNOS-produced RNS are less important in this disease process.

\section{Serum-induced arthritis was a neutrophil-dominant tissue inflammation in both $\mathrm{Ncf1}^{-1-}$ and wild-type mice}

We then analyzed the histology of the inflamed joints of these arthritic mice. We found that while there was no apparent tissue inflammation at the baseline (Fig. 2A, left panels), inflammatory changes were apparent in both wild-type and $\mathrm{Ncfl}^{-/-}$mice 7 days after the arthrogenic serum injection (Fig. 2A, middle two panels). The cell infiltration and pannus formation, however, were more severe in $\mathrm{Ncfl}^{-/-}$mice than in wild-type mice (Fig. 2A, middle two panels). Neutrophils (visualized as myeloperoxidase [MPO]-positive cells) were the dominant infiltrating immune cells in both genotypes, with even more neutrophils in inflammatory joint tissues of $\mathrm{Ncfl}^{-/-}$mice in comparison with the arthritic tissues of wild-type mice (wildtype mice, $179 \pm 50.99 \mathrm{MPO}$-positive cells $/ \mathrm{mm}^{2} ; \mathrm{Ncfl}^{-/-}$mice, 373.4 \pm 60.29 MPO-positive cells $/ \mathrm{mm}^{2}$, Fig. 2A, right panels).

\section{Granulocyte depletion abrogated serum-induced arthritis in both $\mathrm{Ncf1}^{-1-}$ and wild-type mice}

To address whether neutrophils play an essential role in the pathogenesis of serum-induced arthritis in $\mathrm{Ncfl}^{-/-}$mice as well as in wild-type mice, we depleted granulocytes with anti-Gr1 antibody before serum injection in both strains of mice and then analyzed the severity of arthritis (Fig. 2B, C). We found that the neutrophil depletion almost completely suppressed joint inflammation in both $\mathrm{Ncfl}^{-/-}$and wild-type mice, which suggested that the presence of granulocytes is essential for the induction of serum-induced arthritis in the presence or absence of leukocyte-produced ROS.

\section{Higher levels of some proinflammatory cytokines in joints of $\mathrm{Ncf1}^{-/-}$mice than in wild-type mice}

To unravel how leukocyte-produced ROS modulates inflammation in the arthritis model, we compared the cytokine profiles of inflamed joints from wild-type and $\mathrm{Ncfl}^{-/}$mice. 

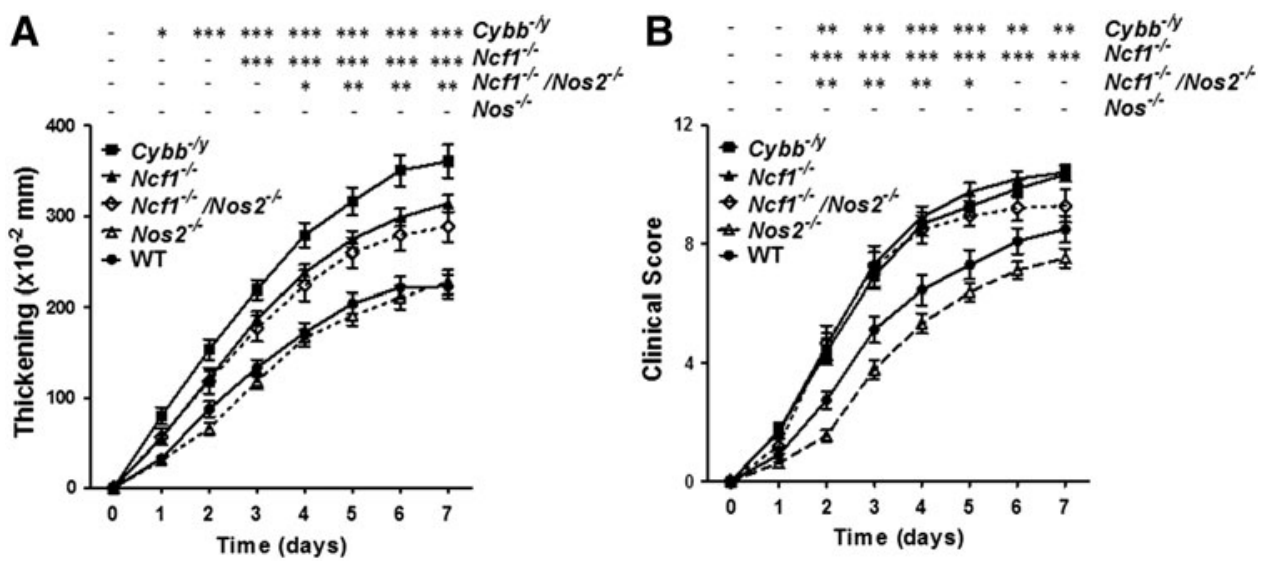

FIG. 1. Increased severity of serum-induced arthritis in NOX2-deficient mice. The severity of arthritis was measured on days 0-7 with increase in thickness (A) and clinical scores (B) after the injection of $\mathrm{K} / \mathrm{BxN}$ serum. The figures indicate the sum of the thickening and clinical scores of all four paws of each mouse. Asterisks indicate significant differences between gene-modified mice and wild-type mice. The results are the combined measurements of five experiments with similar results and shown as mean \pm SEM (wild-type, $n=22 ; N c f 1^{-/-}, n=30 ; C y b b^{-/ y}, n=16 ; N o s 2^{-\prime-}, n=19 ; N c f 1^{-/-}$ $\operatorname{Nos} 2^{-/-}$double knockout, $\left.n=8\right)$. The statistically significant differences between groups are indicated with $* * *$, and $* * *$ $(* p<0.05, * * p<0.01, * * * p<0.001)$, while - indicates lack of statistical significance $(p \geq 0.05)$. NOX2, NADPH oxidase 2 .

We found that tissue levels of proinflammatory cytokines, including IL-1 $\beta$, IL-6, TNF $\alpha$, and IL-17, and keratinocytederived chemokine $(\mathrm{KC})$ tend to increase after serum injection. On day 7 , the levels of IL- $1 \beta$ and IL-6 were significantly higher in arthritic $N c f 1^{-/-}$mice than in wild-type mice, while the levels of $\mathrm{TNF} \alpha$ were similar (Fig. 3A-C). These results suggest that IL- $1 \beta$ and IL- 6 may be more important in increasing the severity of arthritis in ROS-deficient conditions. We also analyzed levels of IL-17 and $\mathrm{KC}$, which are associated with neutrophil recruitment. We found that IL-17 increased in inflamed joints after induction with serum, and $\mathrm{KC}$ trended in the same direction, but there was no difference between these two strains of mice on day 7 (Fig. 3D, E). IL-4 was elevated on day 11 after the serum injection in $N c f 1^{-/-}$ mice, but did not significantly change in the wild-type group.

\section{TNF $\alpha$ neutralization and IL-1 $\beta$ depletion differentially suppressed the severity of arthritis in wild-type and $\mathrm{Ncf1}^{-1-}$ mice}

We went on to test the effects of $\mathrm{TNF} \alpha$ neutralization and IL-1 $\beta$ depletion on disease severity in vivo. We found that antagonism of $\mathrm{TNF} \alpha$ or IL- $1 \beta$ significantly reduced the severity of arthritis in wild-type and $N c f 1^{-/-}$mice (Fig. 4A-D). By comparing the relative suppression of anti-IL-1 $\beta$ antibody and TNF $\alpha$ antagonist in $N c f 1^{-/-}$and wild-type mice, we found that the reduction of arthritis severity from $\mathrm{TNF} \alpha$ neutralization was similar to that of IL- $1 \beta$ blockade in wild-type mice, whereas IL- $1 \beta$ blockade was more effective than TNF $\alpha$ neutralization in NOX2-deficient animals. Whereas the TNF $\alpha$ antagonist, etanercept, suppressed the paw thickening by around $48 \%$ in wild-type mice, it only suppressed the paw thickening by around $23 \%$ in $N c f 1^{-/-}$mice (Fig. 4E). The relative inefficacy of etanercept in the $N c f 1^{-/-}$mice, along with the marked effectiveness of anti-IL-1 $\beta$ antibody in decreasing the joint thickness in these mice, suggests that IL- $1 \beta$, which is significantly higher in the inflammatory joints of $\mathrm{Ncfl}^{-/-}$mice (Fig. 3), plays an important role in enhancing arthritis severity in these mice.
Higher activities of cathepsin B and caspase-1 in arthritic tissue of $\mathrm{Ncf1}^{-/-}$mice than in wild-type mice

To investigate the mechanism underlying the increased IL$1 \beta$ production after inflammatory stimulations, we measured the relative amount of pro-IL- $1 \beta$ mRNA in mouse leukocytes treated with inflammatory stimulations (lipopolysaccharide $[500 \mathrm{ng} / \mathrm{ml}]$ and/or alum $[100 \mu \mathrm{g} / \mathrm{ml}])$ in the presence or absence of exogenous $1 \mathrm{~m} M$ hydrogen peroxide $\left(\mathrm{H}_{2} \mathrm{O}_{2}\right)$. We found that the presence of $\mathrm{H}_{2} \mathrm{O}_{2}$ did not affect the induction of pro-IL- $1 \beta$ transcription in leukocytes after inflammatory stimulations (Supplementary Fig. S2). As pro-IL-1 $\beta$ may be processed by cysteine proteases, including caspase- 1 and cathepsin $\mathrm{B}$, to produce active IL- $1 \beta$, we analyzed the activity of these relevant proteases in inflamed joint tissues from wild-type and in $N c f 1^{-/-}$mice with serum-induced arthritis. We found that both active cathepsin B and caspase-1 levels were significantly higher in $\mathrm{Ncfl}^{-/-}$arthritic tissue than those in wild-type mice (Fig. 5).

\section{Cathepsin inhibitor was more effective in inhibiting the severity of arthritis in $\mathrm{Ncf1}^{-1-}$ mice, while pan-caspase inhibitor treatment was more effective in wild-type mice}

We further investigated the role of cysteine proteases in vivo by treating wild-type mice and ROS-deficient $N c f 1^{-/-}$ mice with cysteine protease inhibitors. We treated wild-type and ROS-deficient mice with two cysteine protease inhibitors, $\mathrm{z}-\mathrm{VAD}-\mathrm{FMK}$ and $\mathrm{z}-\mathrm{FA}-\mathrm{FMK}$, before serum induction of arthritis. Z-VAD-FMK is a pan-caspase inhibitor, while Z-FA-FMK is a cysteine cathepsin inhibitor that can antagonize cathepsin B, S, and L. We found that inhibition of caspase activity with Z-VAD-FMK, but not inhibition with cysteine cathepsins, reduced the arthritis severity in wildtype mice (Fig. 6A). In contrast, the inhibition of cysteine cathepsins, but not caspase, suppressed the joint inflammation in $N c 1^{-1-}$ mice (Fig. 6B). In wild-type mice, combined treatment with Z-VAD-FMK and Z-FA-FMK suppressed the 

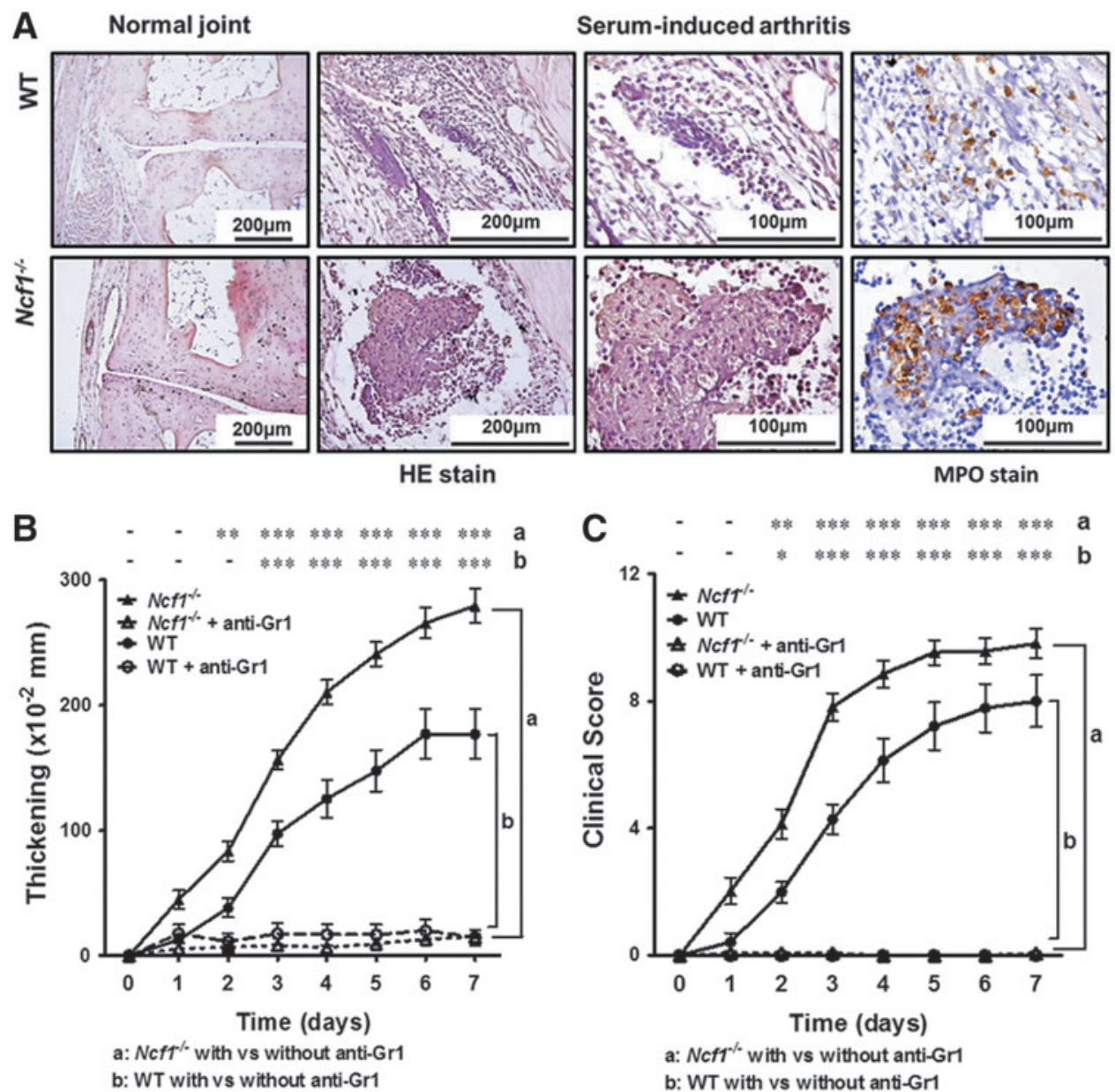

MPO stain

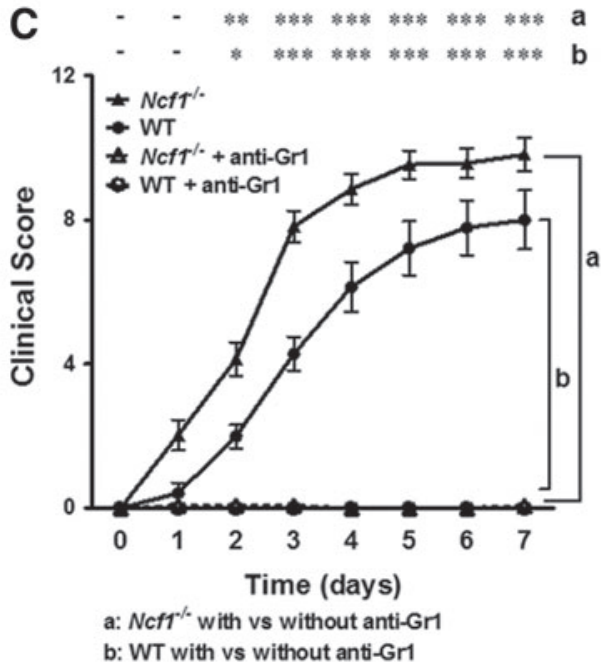

FIG. 2. Serum-induced arthritis is a neutrophil-dominant tissue inflammation, which can be abrogated by granulocyte depletion in both $N c f 1^{-/-}$and wild-type mice. (A) The characteristic histopathological images of H\&E-stained joint tissues from wild-type and $\mathrm{Ncfl}^{-1-}$ mice with or without serum-induced arthritis are shown on the three left panels. Images of immunohistochemial staining with anti-MPO staining are shown in the right panels. The severity of arthritis in wild-type and $\mathrm{Ncfl}^{-1-}$ mice with or without anti-Gr1 treatment was compared. The figures indicate the sum of the thickening (B) and clinical scores (C) of all four paws of each mouse. Asterisks indicate differences between the same mice strains in the presence or absence of anti-Gr1 antibody treatment. The results represent the combined measurements of three experiments with similar results and are shown as mean \pm SEM. Wild-type, $n=8$; wild-type + anti-Gr1 Ab, $n=6$; $N c f 1^{-1-}$, $n=15 ; N c f 1^{-/-}+$anti-Gr1 Ab, $n=10$. The statistically significant differences between groups are indicated with *,**, and **** $(* p<0.05, * * p<0.01, * * * p<0.001)$, while - indicates lack of statistical significance $(p \geq 0.05)$. MPO, myeloperoxidase.

severity of arthritis to a level similar to Z-VAD-FMK treatment alone, while in $\mathrm{Ncfl}^{-/-}$mice, the combined treatment suppressed the severity of arthritis to a level lower than the level in Z-FA-FMK treatment alone. Taken together, these data suggest that while active caspases are important in both wild-type and NOX2-deficient mice, active cysteine cathepsins are more important in causing the joint inflammation in mice lacking leukocyte-produced ROS.

\section{ROS inhibited the capacity of cathepsin $B$ to process human pro-IL-1 $\beta$ to produce active IL-1 $\beta$}

We further examined whether redox regulation of pro-IL$1 \beta$-processing proteases may affect the production of active IL-1 $\beta$ in human cells. To show the protease activity of caspase- 1 and cathepsin $\mathrm{B}$ to process pro-IL- $1 \beta$, we treated human pro-IL-1 $\beta$ protein (molecular weight $34 \mathrm{kDa}$ ) with cathepsin B and caspase-1. We found that after treatment of human pro-IL- $1 \beta$ with caspase- 1 , products of 17 and $15 \mathrm{kDa}$ can be visualized with SDS-PAGE, followed by Western blot with anti-IL-1 $\beta$ antibody detection (Fig. 7A, second lane). The production of these bands was not affected by the presence of ROS when exogenous hydrogen peroxide (up to $0.5 \mathrm{~m} M$ ) was added (data not shown). After treating human pro-IL-1 $\beta$ with cathepsin $\mathrm{B}$, two products with apparent molecular weights of 20 and $15 \mathrm{kDa}$, which are different from the 17 to $15 \mathrm{kDa}$ products after caspase- 1 treatment, were detected with anti-IL- $1 \beta$ antibody (compare second and third lanes on Fig. 7A). The production of these bands was inhibited by the presence of cathepsin inhibitor, Z-FA-FMK, and hydrogen peroxide (Fig. 7A, fourth to seventh lanes). To analyze whether human cathepsin $\mathrm{B}$ has the catalytic activity to produce bioactive IL- $1 \beta$ from pro-IL- $\beta$ to activate inflammatory responses in parenchymal cells (e.g., fibroblasts) such as caspase- 1 , we analyzed $\mathrm{I} \kappa \mathrm{B}$ degradation and $\mathrm{NF} \kappa \mathrm{B}$ phosphorylation in cells treated with pro-IL- $1 \beta$ after different 
A

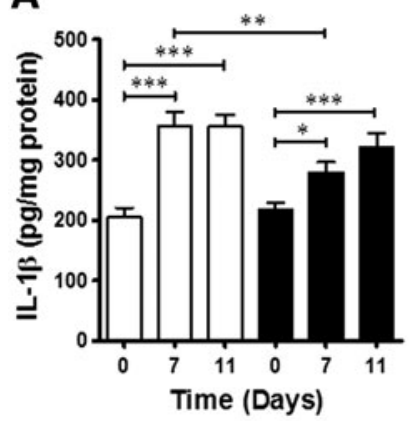

FIG. 3. Different cytokine expression profiles in seruminduced arthritis in $\mathrm{Ncfl}^{-1-}$ and wild-type mice. Wildtype and $\mathrm{NCfl}^{-1-}$ mice wrist homogenates before (day 0$)$ and after (days 7,11) arthritogenic serum injection were quantified for (A) IL-1 $\beta$, (B) IL-6, (C) TNF $\alpha$, (D) IL-17a, (E) $\mathrm{KC}$, and (F) IL-4 with ELISA. The statistically significant differences between groups are indicated with *, $* *$, and $* * *(* p<0.05, * * p<$ $0.01, * * * p<0.001)$. IL, interleukin; $\mathrm{KC}$, keratinocytederived chemokine; $\mathrm{TNF} \alpha$, tumor necrosis factor- $\alpha$.
B
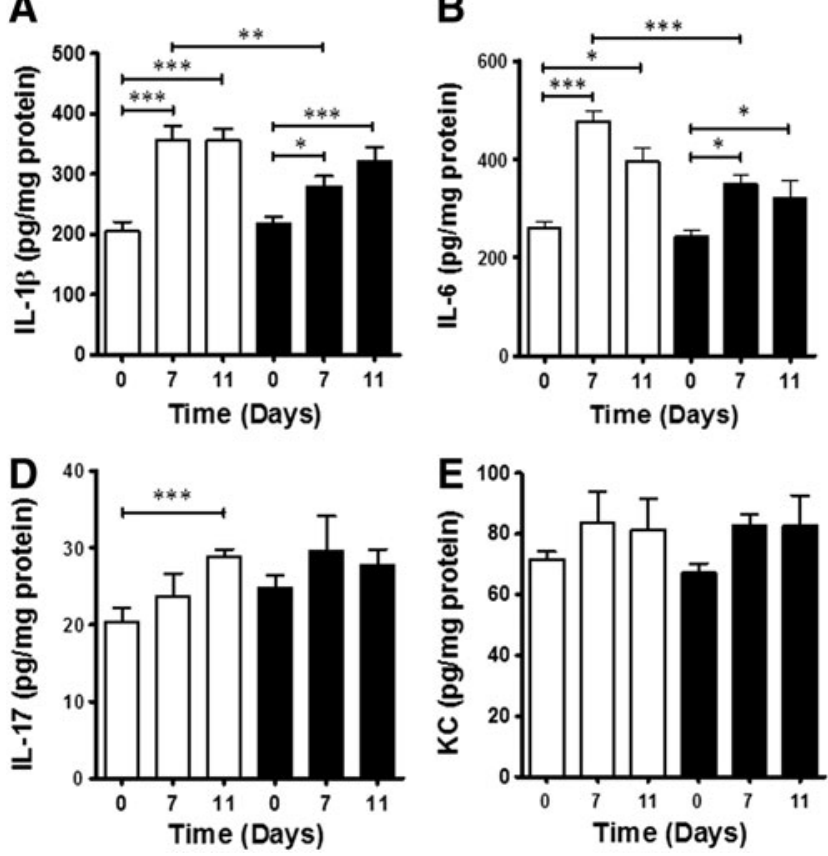
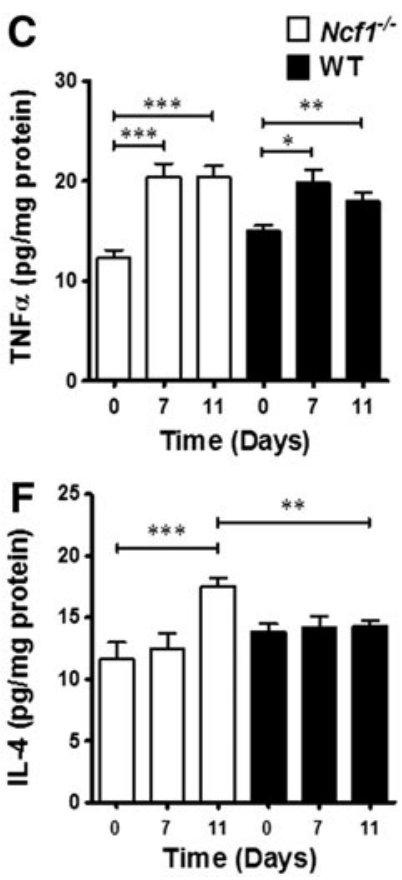

processing. Our results revealed that similar to caspase-1treated pro-IL-1 $\beta$, cathepsin B-treated pro-IL-1 $\beta$ induced $\mathrm{I} \kappa \mathrm{B}$ degradation and $\mathrm{NF} \kappa \mathrm{B}$ phosphorylation in the IMR90 human fibroblast line (Fig. 7B, lanes 1-3). Compatible with the lack of anti-IL- $1 \beta$-reactive cleavage products on the right three lanes of Figure 7A, no induction of $I \kappa \mathrm{B}$ degradation and $\mathrm{NF} \kappa \mathrm{B}$ phosphorylation was found in cells treated with proIL- $1 \beta$ processed in the presence of hydrogen peroxide (Fig. $7 \mathrm{~B}$, lanes 5 and 6 ). We also tested the activity of the processed pro-IL-1 $\beta$ to induce $\mathrm{NF} \kappa \mathrm{B}$ translocation in human fibroblasts. We found that in comparison with nonprocessed pro-IL-1 $\beta$, caspase-1-processed pro-IL-1 $\beta$ induced strong localization of $\mathrm{NF} \kappa \mathrm{B}$ in the nuclei (Fig. 7C, panels 1 and 2). Similarly, cathepsin B-processed pro-IL-1 $\beta$ induced nuclear translocation of NF $\kappa \mathrm{B}$ (Fig. 7C, panel 3). This induced NF $\kappa \mathrm{B}$ nuclear localization, however, was inhibited by the presence of cathepsin inhibitor, Z-FA-FMK, or hydrogen peroxide $(1 \mathrm{mM})$ (Fig. 7C, panels 4 and 5).

\section{Discussion}

To investigate the unique role of ROS in joint inflammation, we used a serum-induced arthritis model in NOX2deficient mouse strains to dissect the effect of oxidative stress in the tissue inflammation in the joints. Based on the findings that mice with deficiencies in NOX2 have more severe arthritis, while mice with defective iNOS have similar responses to wild-type controls, we found that NOX2 plays a more important role in comparison with iNOS and went on to show a characterization of the $\mathrm{Ncfl}^{-1-}$ strain in comparison with the wild-type mice in this study. Our data indicate that the net effect of ROS is to suppress arthritis severity, while RNS play no similar role. Further, cytokine quantitation and inhibitor studies suggest that this effect is likely mediated, at least in part, by the modulation of the activity of cysteine proteases by ROS and therefore the production of active IL$1 \beta$. These results define a new mechanism through which oxidant stress downregulates acute immune-mediated inflammation of the joints.

The pathogenesis of immune-mediated arthritis is complex. Although many mediators and mechanisms have been reported to be involved in the initiation of joint damage and perpetuation of arthritis, the key factors leading to acute inflammation in joints remain elusive. We used the $\mathrm{K} / \mathrm{BxN}$ serum-induced arthritis mouse model, which has been shown to be a good model for studying systemic as well as local inflammation in arthritis in this study. This model avoids the prolonged process of sensitization required for autoantigeninduced arthritis (e.g., collagen or peptide-induced arthritis), which makes it difficult to investigate the initiation of the diseases, and facilitates the investigation on the early inflammatory responses in immune-mediated arthritis. Mice were induced to develop erosive arthritis through injection of autoantibody-containing serum to trigger the induction of inflammatory arthritis $(6,26,39,56)$. Our results confirm that this disease model represents an effective tool to examine the role of innate immune mechanisms in the early effector phase of autoimmune arthritis. While $C y b b$ (encoding gp91phox) has a more restricted expression in leukocytes, Ncfl (encoding p47phox) is more widely expressed in both leukocytes and nonleukocytes. As most in vivo experiments in this study were performed with $N c f 1$-deficient mice, the possibility that lack of p47phox on nonimmune cells may contribute to the differences in wild-type and NOX2-deficient groups cannot be ruled out. However, since we observed a decrease in the severity of arthritis in mice deficient in $C y b b$ and $N c f l$ to a similar extent (Fig. 1), the defect in leukocyte NADPH oxidase is likely to be the major factor regulating the joint inflammation. A recent study by Kelkka et al. used the collagen antibody-induced arthritis model to show the higher level of antibody-induced arthritis in mice lacking ROS production and the role of Toll-like receptors (TLRs) in this process (25). Consistent with the findings in this study, their results also showed that neutrophils are crucial for the characteristic 

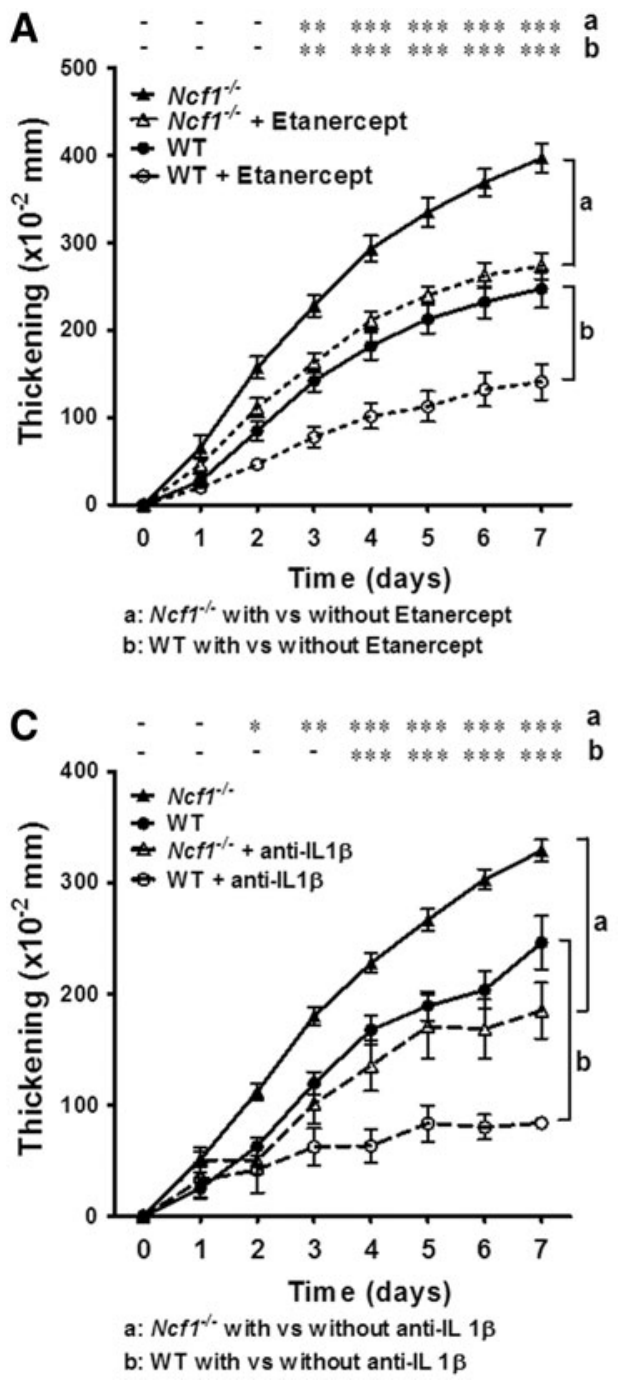
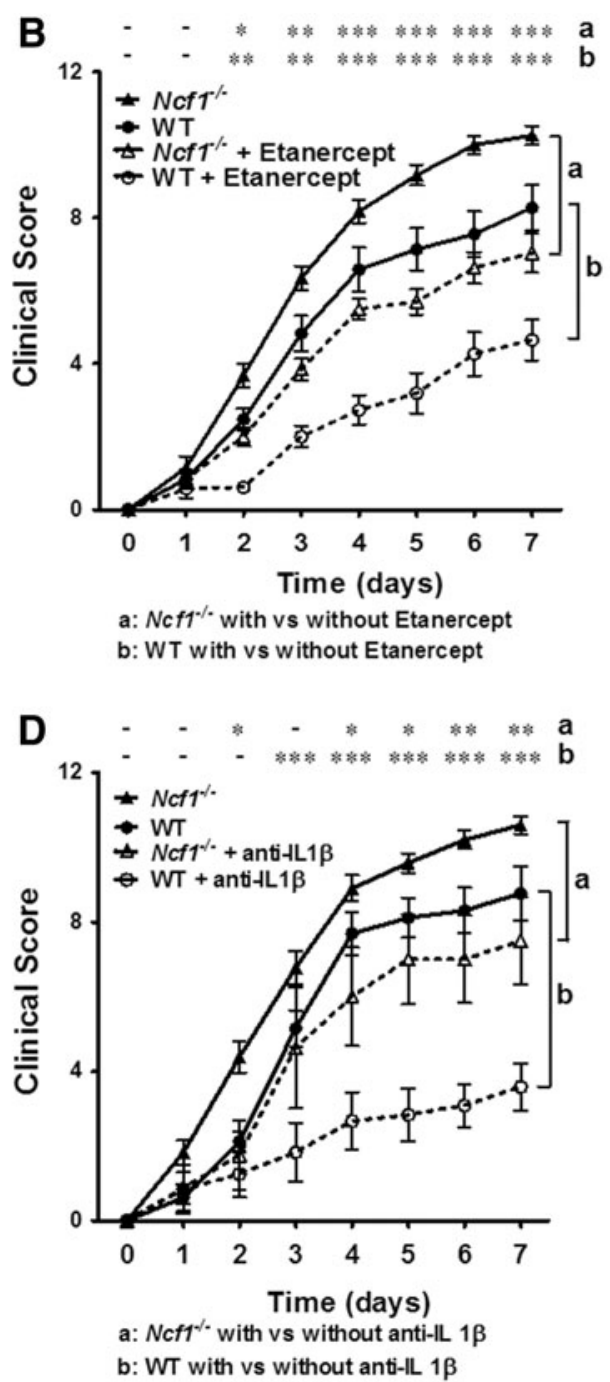

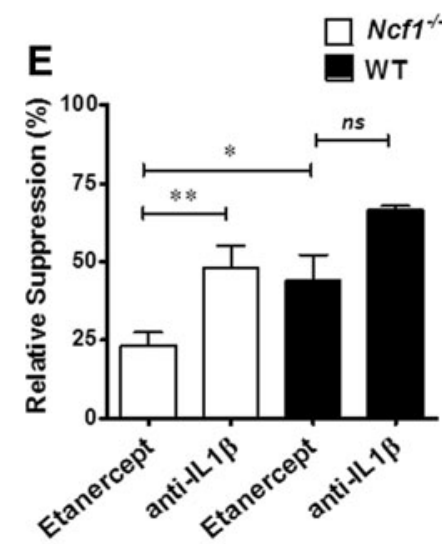

FIG. 4. TNF $\alpha$ neutralization and IL-1 $\beta$ depletion suppress the severity of arthritis in wild-type and $N c f 1^{-/-}$mice to different extents. The effect of TNF $\alpha$ antagonist, etanercept, and anti-IL-1 $\beta$ antibody on the severity of serum-induced arthritis was measured with increase in thickness and clinical scores after the arthritogenic serum injection with or without the treatments. The effects of $\mathrm{TNF} \alpha$ neutralization with etanercept in the severity of arthritis in wild-type mice and in $N c f 1^{-1-}$ mice are shown in (A, B). The effect of anti-IL-1 $\beta$ antibody on the severity of arthritis in wild-type mice and in $\mathrm{Ncfl}^{-/-}$mice is shown in $(\mathbf{C}, \mathbf{D})$. Asterisks indicate differences between the same genotype of mice strains in the presence or absence of cytokine neutralization treatment. Wild-type, $n=16$; wild-type + etanercept, $n=15 ; N c f 1^{-\prime-}, n=17 ; N c f 1^{-\prime-}$ + etanercept, $n=15$ for (A, B). Wild-type, $n=10$; wild-type + anti-IL-1 $\beta \mathrm{Ab}, n=5 ; N c f 1^{-\prime-}, n=27 ; N c f 1^{-\prime-}+\alpha \mathrm{IL}-1 \beta \mathrm{Ab}$, $n=4$ for (C, D). (E) The relative suppression activity by etanercept and anti-IL-1 $\beta$ treatments on paw thickening in wildtype mice and in the $\mathrm{Ncfl}^{-{ }^{-1}}$ group on day 7 were compared. The statistical differences between groups are indicated with $*, * *$, and $* * *(* p<0.05, * * p<0.01, * * * p<0.001)$, while - indicates lack of statistical significance $(p \geq 0.05)$.

enhancement of arthritis severity in mice lacking NOX2 activity. Our results revealing the role of ROS in modulating the processing of pro-IL-1 $\beta$ (Fig. 7 and Supplementary Fig. S3) may partly explain the downstream effects of TLR2 on regulating joint inflammation shown in that study. Moreover, we characterized the different roles of macrophages and neutrophils and found that neutrophils, with or without activation, produced low amount of IL- $1 \beta$, while macrophages can be induced to produce large amounts of IL- $1 \beta$ after activation in both wild-type and $N c f 1^{-/-}$mice. Interestingly, when activated macrophages were cocultured with activated wild-type neutrophils, the IL- $1 \beta$ secretion was significantly suppressed. The $N c f 1^{-/-}$neutrophils, which are defective in the ability to produce ROS, had a weaker activity to suppress the macrophage-produced IL- $1 \beta$ (Supplementary Fig. S3).

Activated innate immune cells, especially phagocytic leukocytes, including granulocytes and macrophages, are known for their ability to produce large amounts of ROS (termed the respiratory burst) to kill infecting microbes (3, $40,51)$. In addition to host defense, oxidative stress conferred by activated leukocytes has been known to play an important role in affecting many physiological processes, including leukocyte trafficking, cell death, antigen presentation, wound healing, and glucose regulation $(35,45,47$, $50,55)$. Oxidative stress also has been implicated in many 
A

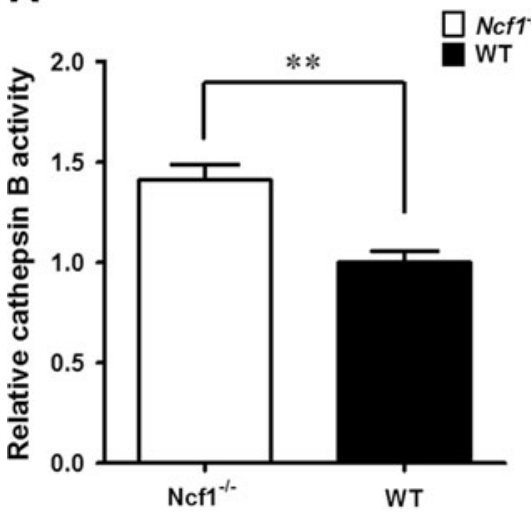

B

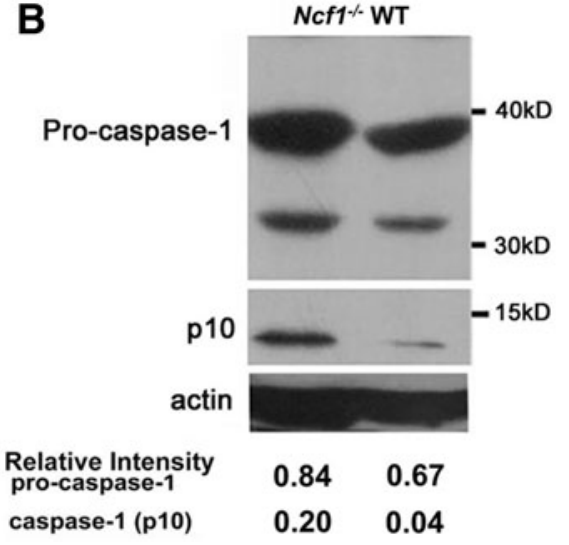

FIG. 5. Higher activities of cathepsin $B$ and caspase-1 in arthritic tissue of $N c f 1^{-/-}$mice than in wild-type mice. (A) Cathepsin B activities in inflamed joint tissues of $\mathrm{NCF}^{-{ }^{-1}}$ and wild-type mice were measured with specific substrate, Z-RRAMC. The graphs show the combined measurements of three experiments with similar results as mean \pm SEM. $* * p<0.01$ compared with the wild-type control group. Wild-type, $n=7 ; \mathrm{Ncfl}^{-1-}, n=14$. (B) The protein expression of procaspase-1 and active caspase-1 (p10) in inflammatory joint tissues of $\mathrm{Ncfl}^{-{ }^{-}}$and wild-type mice was analyzed with SDS-PAGE and Western blot. The experiment was repeated thrice with similar results.

autoimmune inflammatory diseases, most of which are thought to be aggravated by excessive oxidant stress $(23,54)$. Increased neutrophil infiltration is observed in the joints of both wild-type and NOX2-deficient mice with serum-induced arthritis, but was more apparent in the NOX2-deficient mice. Changes in the redox condition in the inflammatory tissue have been reported to modulate the activity of leukocyte adhesion molecules and may directly affect the recruitment of granulocytes into the inflammatory tissues (12, 34). Moreover, higher inflammation states in NOX2-deficient mice may indirectly increase the overall infiltration of leukocytes, including neutrophils in the joints.
The role of ROS in the pathogenic process of autoimmune arthritis, however, has been debated. Some studies support a proinflammatory effect of oxidant stress in arthritis. Kundu et al. found the basal levels of total ROS in neutrophils of patients with RA to be higher than in healthy controls (31). However, other evidence has suggested a potentially protective role for ROS in inflammatory arthritis. Patients with chronic granulomatous disease (CGD), a primary immunodeficiency disease caused by mutations in genes encoding NOX 2 components resulting in a deficiency of ROS, not only suffer from recurrent microbial infections but also experience a hyperinflammation state manifesting as sterile granuloma
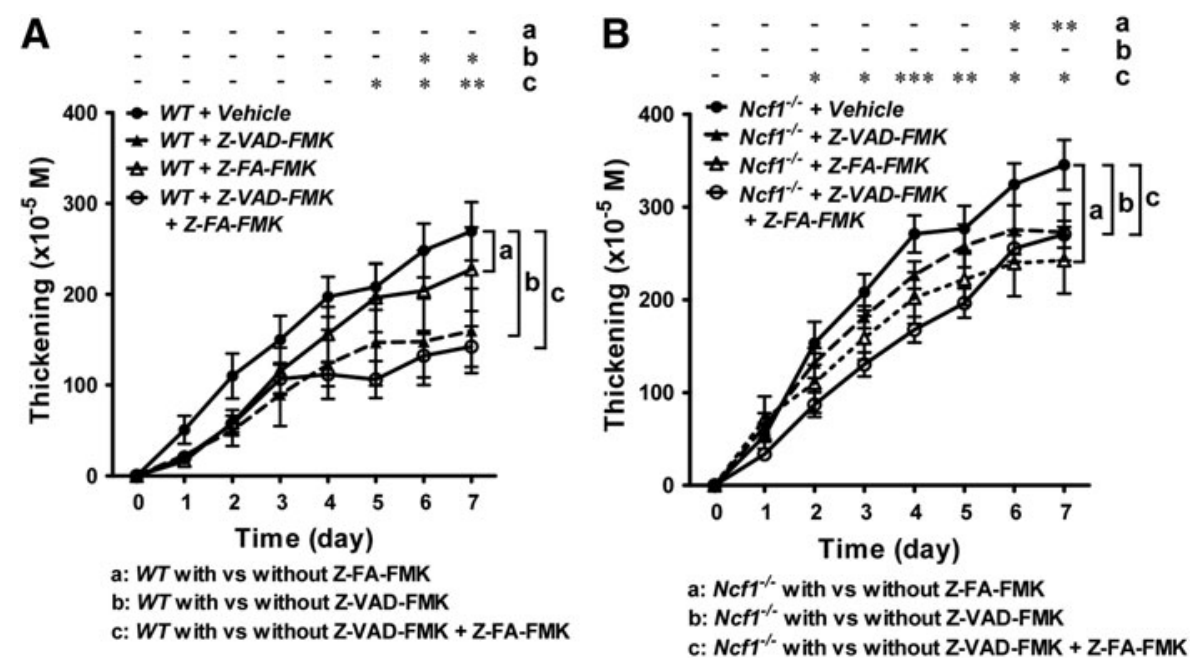

FIG. 6. Cathepsin inhibitor effectively reduces the severity of arthritis in $\mathbf{N c f 1 ^ { - / - }}$ mice. The effect of protease inhibitor treatment in the severity of arthritis in wild-type mice and $N c f 1^{-1-}$ mice. The severity of arthritis was measured with increase in thickness in wild-type B6 mice $(\mathbf{A})$ or $N c f 1^{-1-}$ mice $(\mathbf{B})$ in the presence of pan-caspase inhibitor $(\mathrm{Z}-\mathrm{VAD}$ FMK), cathepsin B inhibitor (Z-FA-FMK), or combined treatment. Asterisks indicate differences between the same genotype of mice strains in the presence or absence of protease inhibitor treatment. Wild-type B6, $n=5$; B6 +Z-VAD-FMK, $n=5 ; \quad \mathrm{B} 6+\mathrm{Z}-\mathrm{FA}-\mathrm{FMK}, n=5 ; \mathrm{B} 6+\mathrm{Z}-\mathrm{VAD}-\mathrm{FMK}+\mathrm{Z}-\mathrm{FA}-\mathrm{DMK}, n=5 ; N c f 1^{-/-}, n=5 ; N c f 1^{-/-}+\mathrm{Z}-\mathrm{VAD}-\mathrm{FMK}, n=5$; $N c f 1^{-/-}+\mathrm{Z}-\mathrm{FA}-\mathrm{FMK}, n=4 ; N c f 1^{-/-}+\mathrm{Z}-\mathrm{VAD}-\mathrm{FMK}+\mathrm{Z}-\mathrm{FA}-\mathrm{FMK}, n=10$. The statistical differences between groups are indicated with $*$, **, and $* * *(* p<0.05, * * p<0.01, * * * p<0.001)$. 


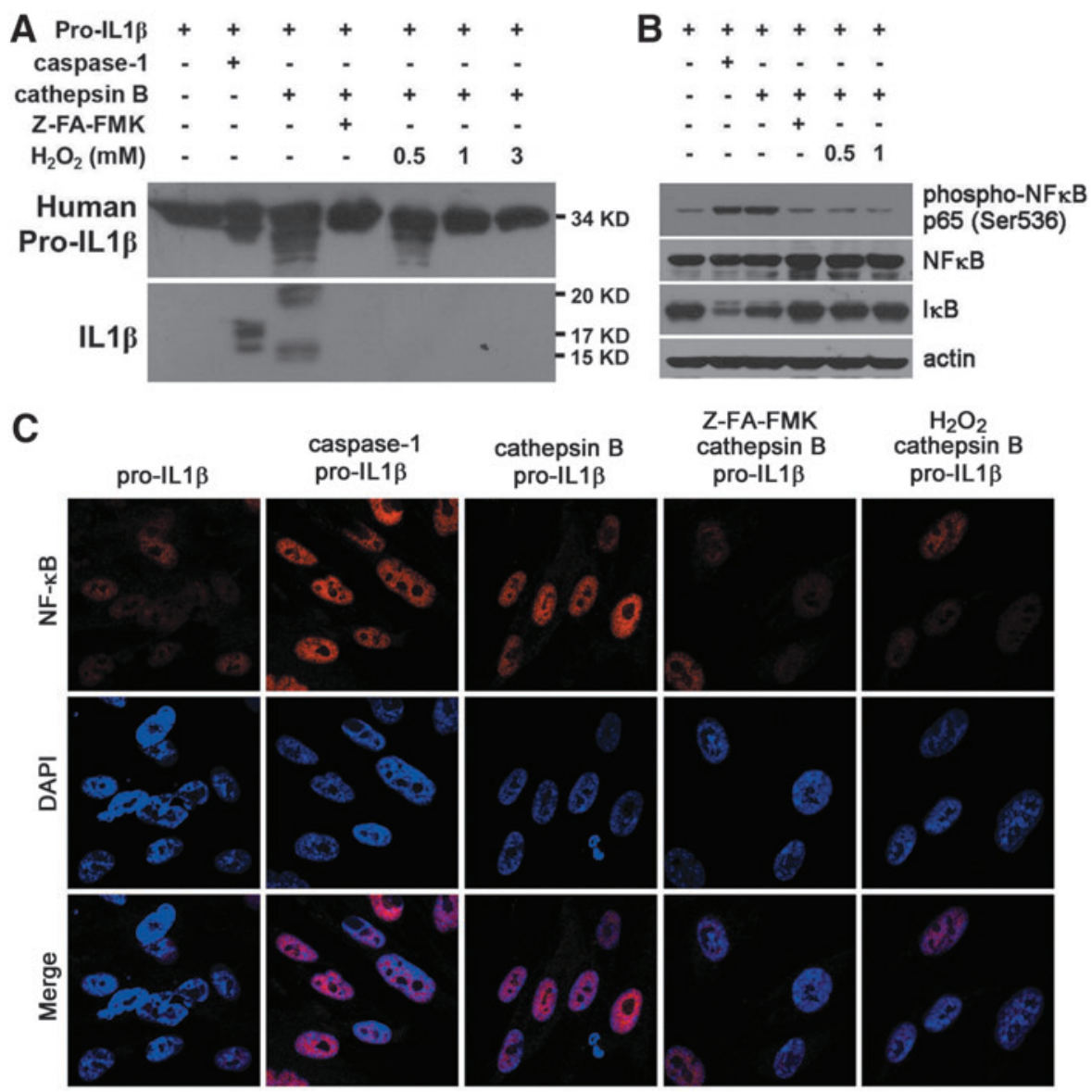

FIG. 7. Oxidant stress inhibits the protease activity of cathepsin $B$ in processing human pro-IL-1 $\beta$ to produce active IL-1 $\beta$. (A) Immunoblot analysis of the effect of purified human cathepsin B in IL$1 \beta$ processing and the effect of $\mathrm{H}_{2} \mathrm{O}_{2}$ in regulating cathepsin $\mathrm{B}$ enzymatic activity. (B) Immunoblot analysis of NF $\kappa \mathrm{B}$ phosphorylation and $\mathrm{I} \kappa \mathrm{B}$ degradation demonstrated the biological effects of cathepsin B-processed IL-1 $\beta$ products in normal human lung fibroblast, IMR90 cells, in the absence or presence of $\mathrm{H}_{2} \mathrm{O}_{2}$. (C) Immunostaining analysis of $\mathrm{NF} \kappa \mathrm{B}$ nuclear translocation demonstrated the effects of cathepsin B-processed IL- $1 \beta$ products in IMR90 cells with or without $\mathrm{H}_{2} \mathrm{O}_{2}$ treatment. Images were captured and analyzed with a linear sequential confocal laser scanning microscope to detect the protein localization. DAPI was used for nuclear staining. Results are representative of three independent experiments. $\mathrm{H}_{2} \mathrm{O}_{2}$, hydrogen peroxide. formation in many different organs $(20,48)$. Moreover, the CGD gene carriers and patients exhibit a higher incidence of autoimmune arthritis and other autoimmune diseases in comparison with healthy controls $(10,13)$. The recent finding that RA patients tend to have lower copy numbers of the NCF1 gene, which encodes the p47phox component of the NOX2 complex, further suggests that NOX2-produced ROS may be protective against the development of RA (43). Indeed, mice with defective NOX2 oxidase may even develop arthritis spontaneously (33). Moreover, NOX2-deficient mice tend to have more severe joint inflammation when they are induced to develop collagen-induced arthritis when compared with control mice (22). By using the serum-induced arthritis model in this study, we were able to pinpoint redox regulation of IL- $1 \beta$ production as the likely cause of increased joint inflammation in ROS-deficient conditions and unravel a potential immune mechanism underlying this unique redox-regulated immune process. Although it has been postulated that ROS may act as second messengers leading to $\mathrm{NF} \kappa \mathrm{B}$ activation, more recent evidences have shown that $\mathrm{NF} \kappa \mathrm{B}$ can be activated normally in cells lacking NADPH oxidase (18). NF $\kappa \mathrm{B}$ mediated inflammatory signals hence can still be transduced in cells without activation-induced ROS production.

Elevated IL- $1 \beta$ secretion by innate immune cells has been reported in human joint inflammation, including RA and JIA (44). IL-1 $\beta$ production requires two signaling steps: transcription of pro-IL-1 $\beta$ (signal 1) and enzymatic cleavage of immature pro-IL-1 $\beta$ (signal 2 ) to produce the biologically active IL- $1 \beta$. Proteolysis of pro-IL- $1 \beta$ can be mediated by caspase-1, which is in turn activated by the assembly of the NLRP3/NALP3 inflammasome complex (52). In addition to caspase-1, other proteases can also process pro-IL-1 $\beta$ (17). Proteases, including elastase, chymase, neutrophil protease 3 , matrix metalloproteases, cathepsin B, cathepsin C, cathepsin $\mathrm{G}$, and chymotrypsin, have been reported to directly or indirectly participate in the proteolytical processing of pro-IL$1 \beta$ to IL- $1 \beta(8,9,17,49)$. Among them, cathepsin B has been predicted to be susceptible to redox control based on the presence of critical cysteine residues (59). Our results showing the activity of cathepsin B to proteolytically process human pro-IL- $1 \beta$ and produce active IL- $1 \beta$ strongly suggest that cathepsin B (and other potential cysteine proteases that are regulated by ROS) is responsible for the increased joint inflammation in NOX2-deficient conditions. A potential approach to address the interaction between oxidant stress and cathepsin B is using mice defective in both the genes encoding NOX2 and cathepsin B. Different from NOX2, which has a more restricted tissue distribution, cathepsin $\mathrm{B}$ has a wide tissue distribution. Although mice with homozygous cathepsin $B$ gene-targeted null mutations (gene knockout) are viable and without gross abnormalities (available from the Jackson Laboratory, Bar Harbor, ME), leukocyte-specific double knockout mice for NOX2 and cathepsin B are currently not available for these experiments. As an alternative, we performed the pan-caspase inhibition and cysteine cathepsin inhibition experiments in wild-type and $\mathrm{Ncfl}^{-/-}$mice to show the relative role of these proteinases in the presence or absence of functional leukocyte, NOX2, shown in Figure 6. 
It has been postulated that cysteine residues on cathepsins confer on them redox responsiveness and add to the longunderstood $\mathrm{pH}$ and metal responsiveness of these proteases through changing the conformation of these enzymes. The metal, redox, and proton factors for the lysosomal cathepsins, especially cathepsin $\mathrm{B}$, have been elucidated in recent studies (36). The newly discovered role for the redox regulation of cathepsin B in this study hence implicates the potential importance of redox modulation of cysteine protease activity as a means of arthritis treatment. How cellular or subcellular molecules mediating redox homeostasis, including thioredoxin (Trx), glutaredoxin, and thioredoxin-binding protein 2 (TBP-2), participate in this process merits further investigation. Recent studies also showed that NLRP3 interacts physically with thioredoxin-interacting protein (Txnip), a key component of the thoredoxin1 (Trx1)-Txnip redoxsensitive signaling complex (60). It has been postulated that under oxidant stress, Txnip dissociates from Trx1 and binds to NLRP3 to modulate the production of IL- $1 \beta$ through caspase-1 (61). How these molecules participate in this critical redox regulation and whether oxidant stress regulates the activity of other proteases (including cathepsins) through similar mechanisms merit further investigation.

Owing to the improved understanding of the underlying immune mechanisms of immune-mediated arthritis, several new biologic agents have been used to treat the diseases. Anti-TNF $\alpha$ therapy is still the most widely used biologic in treating arthritis decades after it began to be used clinically and has resulted in the reduction in inflammation and improvement in quality of life in many patients (14). However, some RA or JIA patients do not respond to anti-TNF $\alpha$ treatment and require other therapeutic methods. IL-1 and IL-6 inhibitors have been used in arthritic patients with favorable results in some patients resistant to anti-TNF $\alpha$ treatment (7, 58). Hence, an immune mechanism-based method to determine the optimal treatment for patients with immunemediated arthritis not only will lessen the suffering and joint disability of the patients but also will be critical for lowering the cost of the treatment. Based on our findings that IL- $1 \beta$ levels were higher in NOX2-deficient mice than in wild-type mice after arthritis induction and that anti-IL- $1 \beta$ antibody is more effective than $\mathrm{TNF} \alpha$ antagonist in suppressing the severity of serum-induced arthritis, it is reasonable to assume that differences in ROS production by inflammatory cells in individual patients may affect the response to these biologic agents. Our new understanding that lack of redox regulation of pro-IL- $1 \beta$-processing proteases in human proteins leads to increased IL- $1 \beta$ production suggests that medication targeting IL-1 $\beta$-mediated inflammation is likely to be the treatment of choice for immune-mediated arthritis in patients with reduced ROS production.

Cathepsin B has been previously reported to activate caspase-1 through interacting with the NLRP3 inflammasome and facilitating the proteolytic processing of pro-IL- $1 \beta$. Proteolytic activation of caspase- 11 by cathepsin B was reported to be involved in this process $(8,9)$. Our results show for the first time that cathepsin B may directly activate proIL- $1 \beta$ to produce bioactive IL- $1 \beta$. This redox-regulated cathepsin B activity, thus may have both caspase-1-dependent and caspase-1-independent pathways to regulate the production of IL-1 $\beta$. Our results (Fig. 6), showing the higher effectiveness of the cathepsin inhibitor in suppressing the joint swelling in NOX2-deficient mice, but the lack of effects of a pan-caspase inhibitor, support the greater importance of cathepsins in tissue inflammatory conditions lacking ROSmediated regulation for the pro-IL- $1 \beta$-processing proteases. Protease inhibition, which suppresses the activity of cathepsins in addition to the inhibition of caspases, hence may be required to effectively inhibit the production of IL- $1 \beta$ in the patients with lower ROS production.

In conclusion, we found that arthritis in NOX2-deficient mice was more severe than wild-type controls, likely mediated, in part, through the lack of oxidative stress-mediated regulation of cathepsin $\mathrm{B}$, resulting in an increase in IL- $1 \beta$. This study sheds important light on the long-sought mechanism of arthritis in NOX2-deficient individuals and reveals a new negative feedback loop through which leukocyteproduced ROS help to moderate the severity of tissue inflammation. In the future, this new understanding of the close relationship between oxidant stress and production of acute inflammatory cytokines may help to define optimal treatment for patients with immune-mediated arthritis.

\section{Materials and Methods}

\section{Mice}

$\mathrm{K} / \mathrm{BxN}$ mice generated from breeding KRN TCR transgenic mice on a C57BL/6 background (kindly provided by Dr. D. Mathis and Dr. C. Benoist, Harvard Medical School, Boston, MA, and the Institut de Génétique et de Biologie Moléculaire et Cellulaire, Strasbourg, France) with NOD mice (purchased from the National Laboratory Animal Center, NLAC, Taiwan) were generated and propagated as previously described by Kouskoff and colleagues (37). Mice deficient in $N c f 1$ [B6(Cg)-Ncf1 $1^{m 1 J} / \mathrm{J}$, No. 004742], in $C y b b$ (B6.129S-Cybb $b^{\text {tmlDin }} / \mathrm{J}$, No. 002365), and in Nos2 (B6. 129P2-Nos $2^{\text {tmlLau }} / \mathrm{J}$, No. 002609) were purchased from Jackson Laboratory. The Ncf1 and Nos2 double genedeficient mice were generated by crossing $N c f 1$-deficient and Nos2-deficient mice. All mice were routinely backcrossed to C57BL/6 background and underwent genome-wide genotyping to confirm the genetic background and were housed in the animal facility of the Laboratory Animal Center at National Cheng Kung University. All procedures were approved by the Institutional Animal Care and Use Committee of National Cheng Kung University. Male mice, aged 10-12 weeks, were used for experiments.

\section{Serum-induced arthritis}

Serum was obtained from $\mathrm{K} / \mathrm{BxN}$ mice at 8-9 weeks of age and stored at $-80^{\circ} \mathrm{C}$. Pooled serum $(75 \mu \mathrm{l})$ from several batches was injected intraperitoneally on day 0 and again on day 2. We used 10- to 12-week-old male mice housed in the specific pathogen-free (SPF) facility in National Cheng Kung University College of Medicine to perform the experiments. Clinical scores were analyzed as the sum of the four limbs, which were given a score of $0-3$ per limb; 0 , no observable swelling; 1, one or two involved digits or mild swelling of the larger structures of the wrist, foot, and ankle, but where the foot shows its normal V shape; 2, between one and three, the long edges of the foot are parallel to each other with disappearance of the original V shape; and 3, severe arthritis, the wrist shows swelling extending along the dorsum of the paw 
to the base of the digits, and the ankle shows the inversion of the $\mathrm{V}$ shape by expansion of the ankle and hindfoot to greater than the width of the forefoot often accompanied by digital swelling. Joint swelling was quantitated as the change in thickness of all four paws as measured with a caliper (Peacock dial thickness gauge with flat anvils; Ozaki Mfg. Co., Ltd., Tokyo, Japan). The measurements were performed before injection on day 0 and once a day after injection from day 1 to 7 or 11 when the mice were sacrificed. Ankle tissues were collected for histological analysis. The infiltration of MPO-positive cells was quantified with TissueQuest cell analysis software (TissueGnostics GmbH, Vienna, Austria) by counting the positively stained cells in nine inflamed areas with leukocyte infiltration from three different mice with each genotype. Wrist tissues were collected for protein and cytokine analysis. For neutrophil depletion or cytokine neutralization experiments, mice were injected intraperitoneally with anti-Gr1 (100 $\mu \mathrm{g} / \mathrm{mouse}$, roughly equivalent to $5 \mu \mathrm{g} / \mathrm{g}$ body weight) or neutralizing antibodies or etanercept ( $500 \mu \mathrm{g} /$ mouse, roughly equivalent to $25 \mu \mathrm{g} / \mathrm{g}$ body weight) on the day before serum injection (day 1) and on day 4 . For protease inhibitor treatment experiments, mice were injected intravenously with protease inhibitors $(160 \mu \mathrm{g} / \mathrm{mouse}$, equivalent to around $8 \mu \mathrm{g} / \mathrm{g}$ body weight) $3 \mathrm{~h}$ before serum injection on day 0 and on day 4 .

\section{Preparation of protein extracts from wrists and ankles}

The wrist and ankle joints were snap-frozen in liquid nitrogen, ground into a fine powder by mortar and pestle, then lysed with protein lysis buffer (1\% Triton X-100, $150 \mathrm{~m} M$ $\mathrm{NaCl}, 10 \mathrm{~m} M$ Tris-base, $1 \mathrm{~m} M$ EDTA, $1 \mathrm{~m} M$ EGTA, pH 7.4, protease inhibitor cocktail; $50 \mathrm{mg}$ specimen per milliliter of lysis buffer), and homogenized on ice for $20 \mathrm{~s}$. The protein extracts from wrist samples and ankle samples were collected for cytokine and protein analysis. Cytokine levels in supernatants (more than five samples for each condition) were measured with ELISA kits (eBioscience, San Diego, CA) in triplicates and performed with the protocols as described by the manufacturer.

\section{Reagents and cells}

Reagents used for cytokine neutralization and cell depletion were as follows: anti-mouse IL-1 $\beta$ (B122 [No. 503504]; BioLegend, San Diego, CA), the TNF $\alpha$ antagonist, soluble TNFR:Ig protein etanercept (Enbrel ${ }^{\mathrm{TM}}$; Pfizer, New York, NY), and anti-mouse Ly6C/G (Gr1) (RB6-8C5 [No. 165931-85]; eBioscience). For protease inhibitor treatment experiments, protease inhibitors, including pan-caspase inhibitor (Z-VAD-FMK [No. FMK001]; R\&D Systems, Minneapolis, $\mathrm{MN}$ ) and cathepsin B/S inhibitor (Z-FA-FMK [No. FMKC01]; R\&D Systems), were used. The IMR90 human lung fibroblast cell line was obtained from ATCC (Manassas, VA; CCL-186).

\section{In vitro determination of protease activities}

Fluorometric determination of cathepsin B activities was performed by incubation of cell lysates in $0.1 \mathrm{M}$ potassium acetate (pH 5.5), $0.01 \%$ CHAPS, and DTT with $5 \mu M$ of fluorogenic substrate, Z-RR-AMC (Sigma, St. Louis, MO). The fluorescent products produced by the enzyme activity were determined at excitation and emission wavelengths of 360 and $460 \mathrm{~nm}$ by using the Fluoroscan Ascent fluorometer (Thermo Scientific, Inc., Waltham, MA) at $37^{\circ} \mathrm{C}$ for $1 \mathrm{~h}$.

\section{Statistical analysis}

The statistical differences between groups on different days after serum injection were analyzed with Student's $t$-test between two groups and one-way or two-way ANOVA when comparing three or more groups using GraphPad Prism software version 5.0 (GraphPad Software, Inc., La Jolla, CA). $p$-Values $<0.05$ were considered significant.

\section{Acknowledgments}

The authors would like to thank Professors D. Mathis (Harvard University), H.K. Sytwu (National Defense Medical College), and P.J. Tsai (National Cheng Kung University) for providing experimental animals and helpful discussion and Professor Marcus Calkins for suggestions about the manuscript. C.C.S. was supported by grants from the National Science Council, Taiwan (NSC 101-2314-B-006-015-MY3), and P.A.N. was supported by the Cogan Family Fund.

\section{Author Disclosure Statement}

No competing financial interests exist.

\section{References}

1. Afonso V, Champy R, Mitrovic D, Collin P, and Lomri A. Reactive oxygen species and superoxide dismutases: role in joint diseases. Joint Bone Spine 74: 324-329, 2007.

2. Agostini L, Martinon F, Burns K, McDermott MF, Hawkins PN, and Tschopp J. NALP3 forms an IL-1beta-processing inflammasome with increased activity in Muckle-Wells autoinflammatory disorder. Immunity 20: 319-325, 2004.

3. Babior BM, Lambeth JD, and Nauseef W. The neutrophil NADPH oxidase. Arch Biochem Biophys 397: 342-344, 2002.

4. Barnes MG, Grom AA, Thompson SD, Griffin TA, Pavlidis $\mathrm{P}$, Itert L, Fall N, Sowders DP, Hinze CH, Aronow BJ, Luyrink LK, Srivastava S, Ilowite NT, Gottlieb BS, Olson JC, Sherry DD, Glass DN, and Colbert RA. Subtypespecific peripheral blood gene expression profiles in recentonset juvenile idiopathic arthritis. Arthritis Rheum 60: 2102-2112, 2009.

5. Bekiaris V, Sedy JR, Rossetti M, Spreafico R, Sharma S, Rhode-Kurnow A, Ware BC, Huang N, Macauley MG, Norris PS, Albani S, and Ware CF. Human CD4 + CD3- innate-like T cells provide a source of TNF and lymphotoxin-alphabeta and are elevated in rheumatoid arthritis. J Immunol 191: 46114618, 2013.

6. Brand DD, Latham KA, and Rosloniec EF. Collageninduced arthritis. Nat Protoc 2: 1269-1275, 2007.

7. Bresnihan B, Newmark R, Robbins S, and Genant HK. Effects of anakinra monotherapy on joint damage in patients with rheumatoid arthritis. Extension of a 24-week randomized, placebo-controlled trial. J Rheumatol 31: 1103-1111, 2004.

8. Broz P, Ruby T, Belhocine K, Bouley DM, Kayagaki N, Dixit VM, and Monack DM. Caspase-11 increases susceptibility to Salmonella infection in the absence of caspase-1. Nature 490: 288-291, 2012.

9. Bruchard M, Mignot G, Derangere V, Chalmin F, Chevriaux A, Vegran F, Boireau W, Simon B, Ryffel B, Connat JL, 
Kanellopoulos J, Martin F, Rebe C, Apetoh L, and Ghiringhelli F. Chemotherapy-triggered cathepsin $\mathrm{B}$ release in myeloidderived suppressor cells activates the Nlrp3 inflammasome and promotes tumor growth. Nat Med 19: 57-64, 2013.

10. Cale CM, Morton L, and Goldblatt D. Cutaneous and other lupus-like symptoms in carriers of X-linked chronic granulomatous disease: incidence and autoimmune serology. Clin Exp Immunol 148: 79-84, 2007.

11. Cascao R, Rosario HS, Souto-Carneiro MM, and Fonseca JE. Neutrophils in rheumatoid arthritis: more than simple final effectors. Autoimmun Rev 9: 531-535, 2010.

12. Chuang KP, Huang YF, Hsu YL, Liu HS, Chen HC, and Shieh CC. Ligation of lymphocyte function-associated antigen-1 on monocytes decreases very late antigen-4mediated adhesion through a reactive oxygen speciesdependent pathway. Blood 104: 4046-4053, 2004.

13. De Ravin SS, Naumann N, Cowen EW, Friend J, Hilligoss D, Marquesen M, Balow JE, Barron KS, Turner ML, Gallin JI, and Malech HL. Chronic granulomatous disease as a risk factor for autoimmune disease. J Allergy Clin Immunol 122: 1097-1103, 2008.

14. Feldmann M and Maini RN. Discovery of TNF-alpha as a therapeutic target in rheumatoid arthritis: preclinical and clinical studies. Joint Bone Spine 69: 12-18, 2002.

15. Firestein GS. Evolving concepts of rheumatoid arthritis. Nature 423: 356-361, 2003.

16. Gizinski AM and Fox DA. T cell subsets and their role in the pathogenesis of rheumatic disease. Curr Opin Rheumatol 26: 204-210, 2014.

17. Guma M, Ronacher L, Liu-Bryan R, Takai S, Karin M, and Corr M. Caspase 1-independent activation of interleukin1beta in neutrophil-predominant inflammation. Arthritis Rheum 60: 3642-3650, 2009.

18. Hayakawa M, Miyashita H, Sakamoto I, Kitagawa M, Tanaka H, Yasuda H, Karin M, and Kikugawa K. Evidence that reactive oxygen species do not mediate NF-kappaB activation. EMBO J 22: 3356-3366, 2003.

19. Hitchon CA and El-Gabalawy HS. Oxidation in rheumatoid arthritis. Arthritis Res Ther 6: 265-278, 2004.

20. Huang YF, Liu SY, Yen CL, Yang PW, and Shieh CC. Thapsigargin and flavin adenine dinucleotide ex vivo treatment rescues trafficking-defective gp91phox in chronic granulomatous disease leukocytes. Free Radic Biol Med 47: 932-940, 2009.

21. Hultqvist M, Backlund J, Bauer K, Gelderman KA, and Holmdahl R. Lack of reactive oxygen species breaks $\mathrm{T}$ cell tolerance to collagen type II and allows development of arthritis in mice. J Immunol 179: 1431-1437, 2007.

22. Hultqvist M, Olofsson P, Holmberg J, Backstrom BT, Tordsson J, and Holmdahl R. Enhanced autoimmunity, arthritis, and encephalomyelitis in mice with a reduced oxidative burst due to a mutation in the Ncf1 gene. Proc Natl Acad Sci U S A 101: 12646-12651, 2004.

23. Kawagishi $\mathrm{H}$ and Finkel $\mathrm{T}$. Unraveling the truth about antioxidants: ROS and disease: finding the right balance. Nat Med 20: 711-713, 2014.

24. Kawatkar AA, Jacobsen SJ, Levy GD, Medhekar SS, Venkatasubramaniam KV, and Herrinton LJ. Direct medical expenditure associated with rheumatoid arthritis in a nationally representative sample from the medical expenditure panel survey. Arthritis Care Res (Hoboken) 64: 1649-1656, 2012.

25. Kelkka T, Hultqvist M, Nandakumar KS, and Holmdahl R. Enhancement of antibody-induced arthritis via Toll-like receptor 2 stimulation is regulated by granulocyte reactive oxygen species. Am J Pathol 181: 141-150, 2012.

26. Khachigian LM. Collagen antibody-induced arthritis. Nat Protoc 1: 2512-2516, 2006.

27. Kitsis E and Weissmann G. The role of the neutrophil in rheumatoid arthritis. Clin Orthop Relat Res: 63-72, 1991.

28. Klareskog L, Amara K, and Malmstrom V. Adaptive immunity in rheumatoid arthritis: anticitrulline and other antibodies in the pathogenesis of rheumatoid arthritis. Curr Opin Rheumatol 26: 72-79, 2014.

29. Kleinman NL, Cifaldi MA, Smeeding JE, Shaw JW, and Brook RA. Annual incremental health benefit costs and absenteeism among employees with and without rheumatoid arthritis. J Occup Environ Med 55: 240-244, 2013.

30. Kowanko IC and Ferrante A. Adhesion and TNF priming in neutrophil-mediated cartilage damage. Clin Immunol Immunopathol 79: 36-42, 1996.

31. Kundu S, Ghosh P, Datta S, Ghosh A, Chattopadhyay S, and Chatterjee M. Oxidative stress as a potential biomarker for determining disease activity in patients with rheumatoid arthritis. Free Radic Res 46: 1482-1489, 2012.

32. Lacy $P$ and Stow JL. Cytokine release from innate immune cells: association with diverse membrane trafficking pathways. Blood 118: 9-18, 2011.

33. Lee K, Won HY, Bae MA, Hong JH, and Hwang ES. Spontaneous and aging-dependent development of arthritis in NADPH oxidase 2 deficiency through altered differentiation of CD11b + and Th/Treg cells. Proc Natl Acad Sci U S A 108: 9548-9553, 2011.

34. Liu SY, Tsai MY, Chuang KP, Huang YF, and Shieh CC. Ligand binding of leukocyte integrin very late antigen-4 involves exposure of sulfhydryl groups and is subject to redox modulation. Eur J Immunol 38: 410-423, 2008.

35. Liu SY, Wang WZ, Yen CL, Tsai MY, Yang PW, Wang JY, Ho CY, and Shieh CC. Leukocyte nicotinamide adenine dinucleotide phosphate-reduced oxidase is required for isocyanate-induced lung inflammation. J Allergy Clin Immunol 127: 1014-1023, 2011.

36. Lockwood TD. Lysosomal metal, redox and proton cycles influencing the CysHis cathepsin reaction. Metallomics 5: 110-124, 2013.

37. Mangialaio S, Ji H, Korganow AS, Kouskoff V, Benoist C, and Mathis D. The arthritogenic $\mathrm{T}$ cell receptor and its ligand in a model of spontaneous arthritis. Arthritis Rheum 42: 2517-2523, 1999.

38. Mariathasan S, Weiss DS, Newton K, McBride J, O'Rourke K, Roose-Girma M, Lee WP, Weinrauch Y, Monack DM, and Dixit VM. Cryopyrin activates the inflammasome in response to toxins and ATP. Nature 440: 228-232, 2006.

39. Monach P, Hattori K, Huang H, Hyatt E, Morse J, Nguyen L, Ortiz-Lopez A, Wu HJ, Mathis D, and Benoist C. The K/ BxN mouse model of inflammatory arthritis: theory and practice. Methods Mol Med 136: 269-282, 2007.

40. Nauseef WM. Assembly of the phagocyte NADPH oxidase. Histochem Cell Biol 122: 277-291, 2004.

41. Nigrovic PA and Lee DM. Mast cells in inflammatory arthritis. Arthritis Res Ther 7: 1-11, 2005.

42. Olofsson P, Holmberg J, Tordsson J, Lu S, Akerstrom B, and Holmdahl R. Positional identification of Ncf1 as a gene that regulates arthritis severity in rats. Nat Genet 33: 25-32, 2003.

43. Olsson LM, Nerstedt A, Lindqvist AK, Johansson SC, Medstrand P, Olofsson P, and Holmdahl R. Copy number variation of the gene NCF1 is associated with rheumatoid arthritis. Antioxid Redox Signal 16: 71-78, 2012. 
44. Pascual V, Allantaz F, Arce E, Punaro M, and Banchereau J. Role of interleukin-1 (IL-1) in the pathogenesis of systemic onset juvenile idiopathic arthritis and clinical response to IL-1 blockade. J Exp Med 201: 1479-1486, 2005.

45. Pepping JK, Freeman LR, Gupta S, Keller JN, and BruceKeller AJ. NOX2 deficiency attenuates markers of adiposopathy and brain injury induced by high-fat diet. Am J Physiol Endocrinol Metab 304: E392-E404, 2013.

46. Rada B and Leto TL. Oxidative innate immune defenses by Nox/Duox family NADPH oxidases. Contrib Microbiol 15: 164-187, 2008.

47. Savina A, Jancic C, Hugues S, Guermonprez P, Vargas P, Moura IC, Lennon-Dumenil AM, Seabra MC, Raposo G, and Amigorena S. NOX2 controls phagosomal $\mathrm{pH}$ to regulate antigen processing during crosspresentation by dendritic cells. Cell 126: 205-218, 2006.

48. Schappi MG, Jaquet V, Belli DC, and Krause KH. Hyperinflammation in chronic granulomatous disease and antiinflammatory role of the phagocyte NADPH oxidase. Semin Immunopathol 30: 255-271, 2008.

49. Schotte P, Van Criekinge W, Van de Craen M, Van Loo G, Desmedt M, Grooten J, Cornelissen M, De Ridder L, Vandekerckhove J, Fiers W, Vandenabeele P, and Beyaert R. Cathepsin B-mediated activation of the proinflammatory caspase-11. Biochem Biophys Res Commun 251: 379-387, 1998.

50. Schroder K, Kohnen A, Aicher A, Liehn EA, Buchse T, Stein S, Weber C, Dimmeler S, and Brandes RP. NADPH oxidase Nox 2 is required for hypoxia-induced mobilization of endothelial progenitor cells. Circ Res 105: 537-544, 2009.

51. Segal BH, Leto TL, Gallin JI, Malech HL, and Holland SM. Genetic, biochemical, and clinical features of chronic granulomatous disease. Medicine (Baltimore) 79: 170-200, 2000.

52. Sidiropoulos PI, Goulielmos G, Voloudakis GK, Petraki E, and Boumpas DT. Inflammasomes and rheumatic diseases: evolving concepts. Ann Rheum Dis 67: 1382-1389, 2008.

53. Striz I, Brabcova E, Kolesar L, and Sekerkova A. Cytokine networking of innate immunity cells: a potential target of therapy. Clin Sci (Lond) 126: 593-612, 2014.

54. Thayer TC, Delano M, Liu C, Chen J, Padgett LE, Tse HM, Annamali M, Piganelli JD, Moldawer LL, and Mathews CE. Superoxide production by macrophages and T cells is critical for the induction of autoreactivity and type 1 diabetes. Diabetes 60: 2144-2151, 2011.

55. Valencia A, Sapp E, Kimm JS, McClory H, Reeves PB, Alexander J, Ansong KA, Masso N, Frosch MP, Kegel KB, Li X, and DiFiglia M. Elevated NADPH oxidase activity contributes to oxidative stress and cell death in Huntington's disease. Hum Mol Genet 22: 1112-1131, 2013.

56. van den Berg WB, Joosten LA, and van Lent PL. Murine antigen-induced arthritis. Methods Mol Med 136: 243-253, 2007.

57. Wipke BT and Allen PM. Essential role of neutrophils in the initiation and progression of a murine model of rheumatoid arthritis. J Immunol 167: 1601-1608, 2001.
58. Woodrick RS and Ruderman EM. Interleukin 6 inhibition-RA and beyond. Bull NYU Hosp Jt Dis 69: 225-229, 2011.

59. Wynn TA, Chawla A, and Pollard JW. Macrophage biology in development, homeostasis and disease. Nature 496: 445455, 2013.

60. Yoshihara E, Masaki S, Matsuo Y, Chen Z, Tian H, and Yodoi J. Thioredoxin/Txnip: redoxisome, as a redox switch for the pathogenesis of diseases. Front Immunol 4: 514, 2014.

61. Zhou R, Tardivel A, Thorens B, Choi I, and Tschopp J. Thioredoxin-interacting protein links oxidative stress to inflammasome activation. Nat Immunol 11: 136-140, 2010.

62. Zwerina J, Tzima S, Hayer S, Redlich K, Hoffmann O, Hanslik-Schnabel B, Smolen JS, Kollias G, and Schett G. Heme oxygenase $1(\mathrm{HO}-1)$ regulates osteoclastogenesis and bone resorption. FASEB J 19: 2011-2013, 2005.

Address correspondence to: Dr. Chi-Chang Shieh Institute of Clinical Medicine

National Cheng Kung University College of Medicine 138 Sheng-Li Road Tainan 70403 Taiwan

E-mail: cshieh@mail.ncku.edu.tw

Date of first submission to ARS Central, September 19, 2014; date of final revised submission, March 21, 2015; date of acceptance, April 9, 2015.

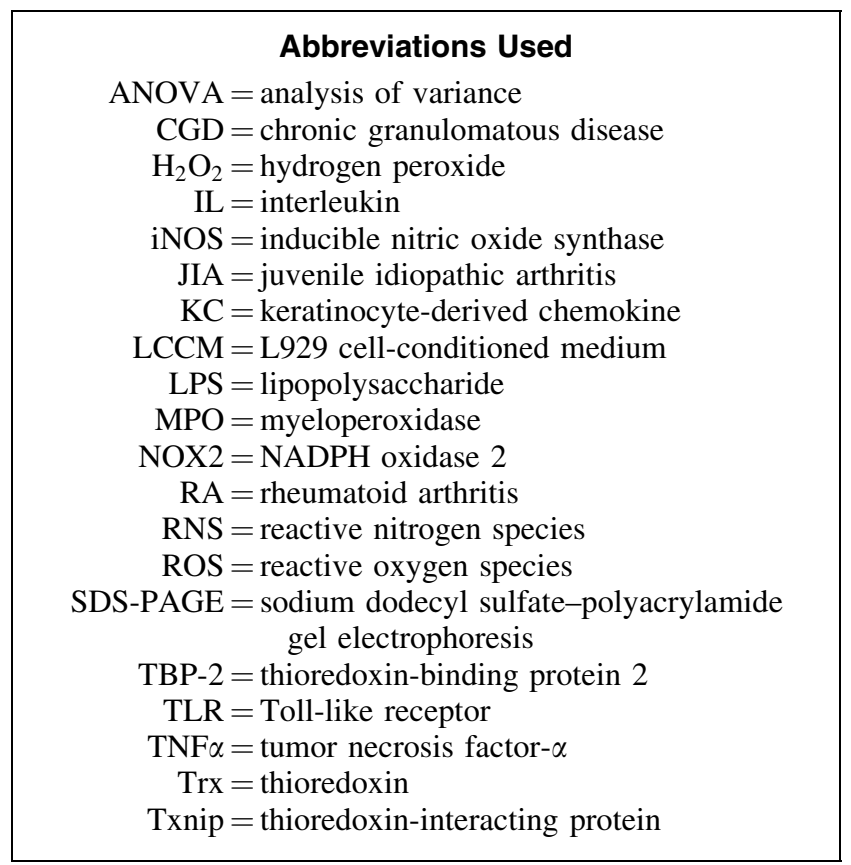

